\title{
Weöres Sándor nyelvköltéséről odda és jaman között
}

1. Weöres Sándor lírai életmúvében számos helyen találhatni a költő által alkotott szavakat, illetőleg ezekkel alkotott szövegmüveket. A költő nyilatkozataiban meg-megemlítette, hogy milyen elemekböl dolgozott, ennek ellenére e szavakat valamely adott nyelvre visszavezetni meglehetősen nehéz.

2. Némelyik kitalált szava többször előfordul műveiben.

2.1. A Bolond Istók címü elbeszélő költeményben ezt mondja a főhős: „Ott láttam Ukkon isten hármas párkányzatú nagy templomát, az ökörnyálon lengedező Ange-Patej úrnő kék szentélyét, a tehenek tőgyét megáldó négy kisasszony cifra faragású tornyát, a fejedelem tölgyfából ácsolt palotáját, a pásztorok és a halászok kunyhóit; benn jártam már a város közepén. Ukkonvárnak hívták ezt a szép várost, nekünk[,] magyaroknak legelső[,] távoli székhelyünket" (Weöres 2013a. 1:346). A magyarság régi idejébe vivő - szatirikus hatású - mitikus történéshez az „Ukkon isten” képzettársítása érthető a karél és finn mitológiából; a Kalevalában is szerepel a mennydörgés, a villám, a felhők istene: Ukko. Az Ange-Pataj név viszont aligha tartozhat ehhez az asszociációs körhöz. A Hangcsoportok (Weöres 2009. 1: 415) Puha, forró hangok [1.] alcímü része ezzel kezdődik:

\author{
Ange amban ulanojje \\ balanga janegol \\ mo hítula e mante \\ u kuaháj imanan. \\ Jekale munni temme \\ a jajja mimenó \\ golopandu ameníja \\ u kuaháj imanan.
}

Az „Ange amban ulanojje” sor amban szava másutt, mondhatni, toldalék nélkül szerepel (A Patakmonda csirája; Weöres 2013b: 315); ugyanitt a mene kapcsán a mene tekel ufarszin 'megszámláltatott, megméretett, feloszlatott' egyik elemére asszociálhat az olvasó, ám ez az ószövetségi kapcsolat, illetőleg a szó (írásképi) hasonlósága bizonnyal véletlen (vö. Bibl. 1976, Dániel 5).

jalean mojun kiszujatté alava - huvoo meü tainkí - kangadleu tonde vo naíkeli humme aszo deni peü vo má - huvdeü haunha kil gela undadé - usszu vea johajo ikü - tebba ankeví lemmü tiu rom íva - holujaju veü vé pí

inkomi talta umu anguvu heba ega - ví jo veo ambo amba tí - antagura hobola onna 
tendi igua - szinnobu jange javé - híkom

heü toagvan beü bítomu ibe - on vom timi lileba

liü gí - hautanto hio hilli lü mene alenne - hau tanti

hoi boü ní geleí

A képzelt város címü versben (Weöres 2013a. 1: 472-474) „zene és ének hömpölyög, mint a tenger" egy templomból:

Juhoa huluma jeniva

emora homeja kullo

tepale meluva...

Jeniva homeja juhoa

kullo tepale...

Ezekről a szavakról BATA (1979: 136-138) úgy gondolja, hogy a ,magyar nyelv azon állapotára utalnak, amikor még a szóvégi hangzók nem koptak le, s a magánhangzórendszer is mintha egy fokkal zártabb volna”. A magánhangzók kapcsán azonban megjegyzendő, hogy csupán három szóban van meg az alapnyelvi örökségü hangrend (Johua, huluma, kullo), a többi szó vegyes hangrendü, a szóvégi hangzókat törölve is - a magyarban e rövid magánhangzók eltünése a 13. század elejéig tartó, több tényezőtől függő folyamat -, csupán egy a kivétel: jeniv(a). Méltóbb a figyelemre az, hogy szó eleji mássalhangzó-torlódás nincsen a költő szövegében. Ez sem valami korábbi magyar nyelvi állapotot jelez, hanem a mássalhangzó-magánhangzó mennyiség kiegyenlítettsége a szöveg zenei hatását növeli. BATA „,nomenverbális” grammatikai szerkezetet (talán nominális stílusú szöveget?) tételez föl, továbbá varázsszövegre emlékeztető szerkezetet. A versben említett „,kisebb-nagyobb csatornák, a Jenu-k és Jado-k” alapján pedig a jeniva szónak valamilyen vízzel kapcsolatos jelentést gondol; a juhoa és a jeniva szavaknak a szövegmüben lévő szerkezeti helyéből átváltozásra, varázsszövegre következtet.

Az amba szóalakot mintha egyszerejtés alakította volna ( $a m b a, a m b a>) a m-$ bamba alakra, mely egyike a költő elképzelt állatneveinek (Bestiárium; Weöres 2009. 3: 217), ám ez nyilván a mai olvasó feltételezése:

A krgak.

A graoo.

A murrago.

A kurgurut.

A bembemtiti.

A golermull.

Az ologanli (vagy koleramadár).

A brbah.

A tüti (vagy kerti tigris).

Az oao.

A trkkalakala.

Az ambamba. 
A Dzsenbimbi (vagy csíkos embryo).

A mboh (vagy börszóró).

A tiptik (folytasd).

Ebben a középkori didaktikus müfajra visszamenő állatbemutatásban a nevek a szó eleji, a magyartól elütő mássalhangzó-kapcsolatokkal azonnal idegen hatást keltenek: $k r-, g r-, b r b-;$; $r k k-, m b-, d z s-$, jóllehet csupán a $b r b-$, a trkk- és az $m b$ - kapcsolatokkal kezdődő szavaink nincsenek. A bestiák neve a szó eleji hangkapcsolatokon kívül a többi is idegen (mondhatni: egzotikus) képzeteket keltő. Az állatnevek humort keltő átírásában Karinthy Frigyes is jeleskedett, száz szójátékot írt újévre 1933-ban, ezek között ekképpen van tigris: „74. Vagyonát vesztett tigris = fatigris [német fatig 'fáradt, kimerült'] + tigris]" (Karinthy 1984: 26). Karinthy szemantikai átértelmezéseket, Weöres egzotikus hangzásképeket készít, amelyekhez néhányszor ad jelentést (,kerti tigris”), de az sem igazítja el biztosan az olvasót („,bőrszóró”). (Ezekhez vö. FORGÁCS 2005: 130-132.)

Néhány egyezés található a Barbár dal (Képzelt eredeti és képzelt fordítás) címü vers (Weöres 2009. 1: 437) szavai és a többi képzelt nyelv között.

Dzsá gulbe rár kicsere

áj ni musztasz emo

áj ni mankütvantasz emo

adde ni maruva bato! jaman!

Ole dzsuro nanni he

ole csilambo ábábi he

ole buglo iningi he

lünlel dáji he! jaman!

Vá pudd shukomo ikede

vá jimla gulmo buglavi ele

vá leli gulmo ni dede

vá odda dzsárumo he! jaman!
Szél völgye farkas fészke

mért nem öriztél engem

mért nem segítettél engem

most nem nyomna kő! ajaj!

Könnyemmel mosdattalak

hajammal törölgettelek

véremmel itattalak

mindig szerettelek! ajaj!

Földed tüskét teremjen tehened véres tejet adjon asszonyod fiat ne adjon édesapád eltemessen! ajaj!

A vá a magyar szöveg alapján morfémaként viselkedik: egyes szám 2. személyü birtokos személyrag: vá pudd 'földed', vá leli 'asszonyod', vá odda 'édesapád'. Hasonló megoldás látható az „ole csilambo ábábi he | ole buglo iningi he” részben is, itt az egyes szám 1 . személyü birtokot jelöli az ole.

A vá szó másutt is megvan. A Sorsangyalok vázlata címü vers jegyzeteként ezt írja a költő: „Akár az »Eidolon«, e vázlat is ebből a négy értelmetlen sorból keletkezett: naur glainre iki | vobe gollu vá| tian plitei keumu tié| hom vonnon $m i$ - oly módon, hogy megpróbáltam a négy sor értelmét, hangzásuk nyomán, megsejteni" (Weöres 2013b: 314); - az Eidolon majd Az áramlás szobra címen jelenik meg kötetben. A vers megírásáról Fülöp Lajosnak részletesen ír egyik levelében (Weöres 1998. 1: 449-466). A négy sor \{magyar nyelv\}: \{képzelt nyelv\} viszonyban van az Arany kés forog (Weöres 2009. 1: 404) címü versben: 


$\begin{array}{ll}\begin{array}{l}\text { arany kés forog } \\ \text { a telt szívben és fönn } \\ \text { arany kés forog }\end{array} & \begin{array}{l}\text { naur glainre iki } \\ \text { vobe gollu vá } \\ \text { naur glainre iki }\end{array} \\ \begin{array}{l}\text { fény pattog éles szilánk } \\ \text { arany kés forog } \\ \text { a telt szívben és fönn }\end{array} & \begin{array}{l}\text { tian plitei keumu tié } \\ \text { naur glainre iki } \\ \text { vobe gollu vá }\end{array} \\ \text { se határ se út } & \text { hom vonnon mí } \\ \text { fény pattog } & \text { tian plitei } \\ \text { a telt szívben } & \text { vobe gollu } \\ \text { éles szilánk } & \text { keumu tié } \\ \text { arany kés forog } & \text { naur glainre iki } \\ \text { a telt szívben és fönn } & \text { vobe gollu vá } \\ \text { fény pattog éles szilánk } & \text { tian plitei keumu tié } \\ \text { se határ se út } & \text { hom vonnon mí }\end{array}$

A vobe gollu vá sorhoz a telt szívben és fönn megfeleltetést adja a költö; a vobe gollu magyarra fordított sora: a telt szívben. A vá tehát 'fönn' jelentésünek tartható, a vobe a '(a) telt' jelentésnek - ha az elképzelt nyelvben is a jelzó a jelzett szó előtt áll -, a gollu a 'szív' jelentésű főnévnek felel meg (és így szinte mindegyik magyar szó helyettesíthető). Az e versbeli vá tehát nem azonos jelentésü a weöresi költői nyelvböl már ismeretesekkel. (Az effajta nyelvezetü Weöres-versek keletkezéstörténetéhez 1. KENYERES 1983: 104-108.)

Ugyancsak megtalálható a vá a színjátékok címtelen betétversei között (Weöres 2013b: 60). A holdbeli csónakos (Weöres 1970a. 1: 457) szereplője, a „Lapátos hindu" ugrál és énekel, mert híradásáért száz aranyat kapott:

Erdő járnyi, gally szennyi

soha többet nem mennyi,

mától kezdve ur lennyi,

mint a kutya pihennyi.

Om vá! om vá! nidhájó vá! om vá!

Ez a vá a nyugat-dunántúli nyelvjárást felidéző rész elemeitől - ur 'úr', szennyi 'szedni', lennyi 'lenni', pihennyi 'pihenni' - élesen különbözve szanszkrit imaformula része, amely rendkívül szent, ugyanakkor értelmetlen szóhalmaz (1. SCHMIDT 1923: 51). Egyetemi hallgatóim ezt a sort ugató-vonyító kutya hangjának vélték. Van példa Weöres lírájában állathangutánzásra is. Nem valamely szokásos hangutánzó szót használja, hanem maga alkot ilyet a Tandori Dezsőnek címü vers végén: ,és a föl nem tett | kérdésre felelet: sose mindegy | ha mindegy [...] vagy a madarak nyelvén: máti mike tái | mata púi pui" (Weöres 2009. 1:315). $\mathrm{Az}$ ornitológusok leleményesen írják le a madárhangokat, az énekesmadár-al- 
katúak hangjaira példának efféléket találunk: ti-u, csi-tiri, lu-lu-lu; csrri, kiir, pszip; pszüb-pszüb, trüi, szr; szrik, hjui, tiri-tiri-tir-ter-ter; stb. (Peterson 1972: 160-184), Weöreséhez hasonló hangsor eddigelé nem akadt. A Weöres-versekben persze nem okvetlen kell valóságos madár (állat) hangjára gondolni, ámbár a Kígyó címü versében (Weöres 2013b: 65) (mondhatni) valóságos az állathang - „szí-szú, szí-szú, | ha nyakukat átharapnám, ha vérüket szívogatnám” -, másutt (zenei) hangulatteremtésre növénynevekkel kapcsolatban is használ hangfestést: „Ibolya, ibolya, plem, plem, | szerelem hasogat engem, | elhervad a zsibavirág, | engem meg a nyavalya rág, | plem, plem, plem - plimm!" (A holdbeli csónakos c. színjáték címtelen betétverse, Weöres 2013b: 63). A plem szó egyébként Karinthy Frigyes nyelvében is megvan, egyik karcolata elején és végén két sakkozó így beszélget: „Plem, plem. [Bek.] - Plem, plem? Hogy mondta: plem, plem? [Bek.] Voltam bátor" (Karinthy 1956: 313). A sakkozók beszélgetésében a plem voltaképpen fatikus szerepü (JAKOBSON 1969: 223), azonban jelentése miatt humoros, groteszk; a korabeli kötetlen társalgási nyelv használta a német plemplem 'bolond, ütődött' szót, amelynek plömplöm alakváltozata ma is él (1. ÉrtSz., TESz., ÉKsz. ${ }^{2}$ ); a szót magyarázat nélkül töltelékszónak tartja LADÁNYI (1961: 300). A weöresi fölhasználás ráértésnek is tartható, hasonlóképp a Karinthyé is: előbbinél a szerelem köti le a személyiséget, utóbbinál a sakkozás, olyannyira, hogy a külső szemlélö ütődöttnek vél(het)i a beszélőket.

Az értelmetlen sorokról szóló Weöres lírai nyelve némely vonásában a neoavantgarde lettrista irányzatának nézeteivel rokon; a lettrizmus a zeneiség fontosságának igénye mellett az értelmetlen szövegek alkotását mủvelte. Ez a költői irányzat 1947-ben indult a francia Isidore Isou kiáltványával, viszont A Patakmonda csírája 1941-ben, a Barbár dal 1944-ben, a sírvers 1945-ben, a Képzelt város 1947-ben készült, illetőleg látott napvilágot. Évtizedek múlva írja Weöres a 18. századi Amade Lászlóról: „eljut az értelmetlen dalolásig, a semmilyen-nyelvü modern lettrizmusig, a vakszövegig: »Dini dini Mimi,| Rimini, | Terci ferci en-ó-nó | Glágla glúglú palenó, | No koleno « (WEÖRES 1977: 296). Weöres hasonló hanghatású szövegrésze: „Azért hogy én eszem-iszom, dindini dinele, | árnyékom is jól él bizony, din don dunele" (Magyar etüdök, 21; Weöres 2013b: 513). A költöi nyelv efféle jelenségeire már egyetemi doktori értekezésében is utalt: „a versekbe a néha jelentéstelen hangcsoportok is kerülnek, hangutánzás vagy hangulatkeltés céljából; pl. Goethe »Zigeunerlied«-jében: »Wille wau-wau-wau! Wille wo-wo-wo! Wito-hu! « Ilyenkor a vers átmenetileg nem a »fogalom müvészete«, hanem teljesen auditív, mint a zene" (WEÖRES 1970b. 1: 211). Nyilvánvaló: Weöres saját gyakorlatában a már említett Hangcsoportok további darabjai is effélék:

Gyors, gyöngyözö, vidám hangok [2.]

Vikulili hejriri szigagga

mukofoki kupukájlili vikufuja

kej rubu lofu-lofu

rudozori klitpipa kejrila. 
Áradó, sugárzó hangok [3.]

Khúnái áfháiszthái mengoh

álkén ovai lái!

mánéshgoli ken unnuloj mopi

aljoj ken oszándeszthái!

A költő a ,jelentéstelen hangcsoportok"-nak mondott elemekből épített egyik verséhez ([Galumbe tinaibe vai], Weöres 2013b: 521) megadja a szószedetet:

Galumbe tinaibe vai

hollu ingide mivo ande

kal anen gelau nihuju voe

pelu hau timme innina

tobun aun ejiva iha pelle

gu anguva talalla nenu ean

$\begin{array}{ll}\text { galumbe: } & \text { gyenge, puha, langy } \\ \text { tinaibe: } & \text { fehér, viasz, fátyol } \\ \text { vai: } & \text { forró, piros, sírás } \\ \text { hollu: } & \text { tompa, komoly, redős } \\ \text { ingide: } & \text { fürge, mozgékony, víg } \\ \text { mivo: } & \text { tartalom, korsó, szomj } \\ \text { ande: } & \text { változó, cserélö, napszak } \\ \text { kal: } & \text { egyenes, fa, kemény } \\ \text { anen: } & \text { rokon, kapocs, öltöny } \\ \text { gelau: } & \text { fül, tekervény, út } \\ \text { nihuju: } & \text { táncos, mozgó, női } \\ \text { voe: } & \text { csalódott, elvetélt, határozatlan } \\ \text { pelu: } & \text { pehely, szőrzet, takaró } \\ \text { hau: } & \text { visszhangzó, mély, öblös } \\ \text { timme: } & \text { csúcsos, fú, zár } \\ \text { innina: } & \text { utódnő, papnő, eladólány } \\ \text { tobun: } & \text { zárt, keskeny, egész } \\ \text { aun: } & \text { egy, benne, bukott } \\ \text { ejiva: } & \text { kürt, fuvola, dob } \\ \text { iha: } & \text { kiáltás, lepel, láng } \\ \text { pelle: } & \text { ujj, mozgó, állati } \\ \text { gu: } & \text { cső, tartam, idő } \\ \text { anguva: } & \text { város, erőd, zár } \\ \text { talalla: } & \text { lépkedni, menni, menő } \\ \text { nenu: } & \text { [Nincs jelentés - B. L.] } \\ \text { ean: } & \text { belső, végső, dísz } \\ \end{array}$


Ezt a szószedetet összevetve a korábbi weöresi szóanyaggal, nem találhatni egyezéseket. Afféle régi magyar jelleg sincsen, aminőt BATA vélt látni A képzelt város anyagában, a stílus itt valóban nominális jellegú. A szavak többsége vegyes hangrendü, egyikben-másikban a magyarban szókatlan hangkapcsolatokkal: hau, aun, ean. A magán- és mássalhangzók számában alig van különbség, mássalhangzó-torlódás ezekben sincs. A jelentésekhez kapcsolt szóanyag részletes hangstilisztikai vizsgálata a költői nyelv hangtanában szokásos lehetőségek szempontjából nehezen hozhatna eredményt (FÓNAGY 1989²: 7-88).

2.2. Bizonnyal saját alkotású „értelmetlen”, viszont hangfestő szavak vannak a költő saját magáról szóló „ócska” sírversében is: „facér lépted vígan kocogott a sikátor | macskafejes kövein: gilkili-gilkili-gunn". (Ócska sírversek - [Itt nyugszik W. S.]; Weöres 2009. 2: 389. E vers változatait az 1945. évből 1. Weöres 2013b: 308-309.) Ezek sem lelhetők föl másutt lírájában. A gilkili-gilkili-gunn hangutánzó hapax legomenon: a lépések hangja a kövezeten, amelynek a $g: k$ zöngés-zöngétlen felpattanó zárhangok és a legvilágosabb magánhangzó, az $i$ ismétlődései adják tonalitását a legsötétebb magánhangzónak, az $u$-nak (zenei) zárlatával, amely a zöngés $g$ hangsorozatot az ismétlődő, a szelíd tartalmaknál gyakrabban észlelhető $l$-ek és a hosszú nazális $n n$ kellemesebbé old (vö. FóNAGY 1989²: 34-37). A költő a főszövegnél magasabb hangfekvésben mondja a teljes szerkezetet (1975-ből való hangfelvételemen), így is érvényesül a gunn szóval is jelzett lépések eltérő hangszíne.

A világos és a sötét magánhangzók ellentétének hatását más hangfestő alakulatokban is kihasználja a költő összefüggésben a tartalmas szavak hasonló csoportjával, illetőleg a „csend hangjá”-nak mint hiányzó ingernek érzékeltetésével: „tillilli $\mid$ tillilli $\mid$ tillilli $\mid$ itt nyílj ki $\mid$ itt nyílj ki [...] || ... tallallalla $\mid$ tallallalla $\mid$ tallallalla $\mid$ csönd hangja" (A holdbeli csónakos; Weöres 2013b: 64); hasonló fölépítésủ a már szóba jött Szí-szú, szi-szú is.

A sírvers befejezésében réjaszerü szövegmondat van: „Frászkarikán szánkáz kutyafarka varangyos a banda | híj csóré héláh! Béke legyen porodon!”. Ebben a csóré cigány eredetü, a romani čorro 'szegény; árva' melléknév többes számú alakja (čorre), főnévként lehet vocativusi alak is (vö. csóré: TESz.; csoró: EWUng). Weöres számos népnyelvi réját használ a magyar népköltészeti, népi hangulat és nyelvi környezet fölidézésére; csupán egy példa: „Holnap elsül a hatökör, | elsüti majd a Dömötör, | ihajja, csuhajja!" (Csalóka Péter színjáték címtelen betétverse; Weöres 2013b: 71). Az ÚMTsz. a hij mondatszót ökör, marha, ló terelésére, hajtására használatosnak tudja ( $h i{ }^{2}$ a.). - A csóré mint melléknév 'meztelen, pőre, cigány(os)' stb., főnévként 'meztelen személy, cigány' (1. ÉrtSz., NSzt.) jelentésekben van meg; az ÚMTsz. is sok jelentést, sokféle használatot jegyez ('csupasz, sovány, bolondos, hirtelen beszédü'; 'cigányfiú, bolondos, féleszü suhanc, csavargó, hübelebalázs'), többek között csouróu 'sovány disznó' jelentést is, amely szinte illik a hij $\sim h i j$ indulatszóhoz a weöresi szöveghelyen. A fiatal Weöres egyébként ,ahogy tudott, segített apja gazdaságában, borjút, tehenet, disznót őrzött, szőlőt fattyazott" (KENYERES 1985: 24). A költő egyik versében utal is erre: „Kis falun élek, disznóinknak a korpát tejjel magam keverem” (Levél Füst Milánnak; Weöres 2013. 1: 111); kézenfekvő: ismerte az állatterelgető szavakat. Az $i$-s szavak cigányos beszédmód érzékeltetésének része: „Reselt figét ezseknek, 
nem muzsikát [...], szúrják le elíbb a hegedi árát!" (Mikszáth 1960. 1: 231; vö. SZATHMÁRI 1958: 21). Mindez nem támasztja alá azt a cigányos akcentust, amelyről a költő a Barbár dal kapcsán beszélt (l. alább), ez az akcentus még a Cigány címü verse szövegében is alig fedezhető föl: „Éc | péc | kapuléc, | Csimpilimpi hova mész?" (Weöres 2009. 2: 209). Az MNSzt. egyetlen előfordulását adatolja a csimpilimpi szónak a diáknyelvből (HoFFMANN 1996); vö. ÚMTsz. csimpiszli 'pajkos <gyerek>'. Minthogy a banda 'cigányzenészek csoportja' szónak társulási valenciája van a csóré 'cigány' jelentéssel, ezzel együtt bizonyos „cigányos akcentus" észlelhető. A frászkarika Európa-szerte ismeretes gyógyító, sült tésztából készített kerek perec, amelyen átbújtatták a beteg kisgyermeket, mágikus eszköz, nem cigányos jellegü (ERDŐDI 1954). A frászkarika szót durva stílushatásúnak minősíti az ÉrtSz., az ÉKsz. ${ }^{2}$ „,bizalmas” megjegyzést is ad.

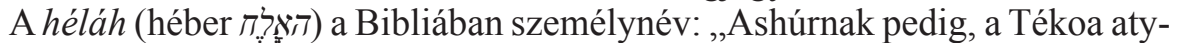
jának volt két felesége, Heléa és Naára" (KárBibl. [1590] 1 Krón. 4, 5). Ugyanígy megvan a szó a héber szöveg ennek megfelelö részében: „Gedeon pedig elméne, és elkészíte egy kecskegödölyét és egy efa lisztből kovásztalan pogácsákat, és betevé a húst egy kosárba, és a hús levét fazékba, és kivivé hozzá a cserfa alá" (KárBibl. [1590] Bír. 6, 19) ezt a cserfá-t (דלָא) terebint(fá)-nak is szokták fordítani. A héláh egyébiránt 'rozsda' jelentésü. A név alakja az újabb magyar fordításokban Helah (Bibl. 1976), Helá (Bibl. 1975); az átírás változatos másutt is: Vulg. Halaa; angol fordításban: „And Ashur the father of Tekoa had two wives, Helah and Naarah” (The Holy Bible), németben: „Aschhur aber, der Vater Tekoas, hatte zwei Frauen: Hela und Naara" (Lutherbibel 1984).

Kis valószínüséggel szóba jöhet a héláh magyarázatára olvasati hiba is, ami az etimológiák végső és (leg)gyengébb megalapozású fajtája. Esetleg a fr. hélas 'sajnos; jaj' szó a kiindulás. Ezt Arany János is használta az Elveszett alkotmányban: „[Hamarfy] Fagylaltat csemegéze, zuhanyt vőn: hélas! hiában! | Gyomra motóláit megakasztani nem vala képes" (AranySz. hélas). A szövegrész könynyen megmaradhatott Weöres emlékezetében, hiszen maga is kedvelte az efféle groteszket, esetleg szándékosan alakította ki a hélá-t, amelynek jelentése illik a szövegegészhez. A fiatal Weöres mestere, Füst Milán a fr. néant szót több helyütt is nean-nak írta, fejtörést okozva kiadóinak, jóllehet tanult franciát (1. BÜKY 2008).

A vers szóban forgó részét SzEPES (1995: 151) „durva káromkodás”-nak tartja, amely „maga még nem is olyan alpári - mert hiszen szellemes”. Sajnos arról nem tesz megjegyzést, hogy melyik szavak jelentése(i) miatt van itt szellemes káromlás.

A híj csóré héláh kitétele mindenesetre ellenpontja a verskezdetnek: „Mántikaténi katá... Már arcod esőben elolvad, | hüs földben kisimúl csöngei boglya-hajad" (Weöres 2009. 2: 389). Megjegyzendö, hogy a kiadás idézett helyén a katá tévesen kátá, a híj pedig hij; vers első kötetbeli és későbbi kiadása (Weöres 1968: 149, 1970. 2: 584) tanúsítják a disztichonban írott vers helyes szövegét:

$-U U|-U U|-||-|-U U|-U U \mid--?$

mán ti ka té ni ka tá már ar cod e sö ben el ol vad? 


\section{$--|-U U|-||-U U|-U U|-?$}

hüs föld ben ki s múl csön ge i bog lya ha jad:

A mántikaténi katá mint sírvers(kezdet) antik thrénoszmintákat, ókori gyászdalokat követ (verselésben is). Mantikaténi szó nincs a klasszikus görögben; van azonban $\mu \alpha \eta \tau \imath \kappa \alpha$ (mantika) 'jóslással kapcsolatos, jós-' melléknév (neutrumi alak), illetőleg ebből képzett, fogalmat jelentő főnév ('jóslás; jóslással kapcsolatos dolgok'). A téni része a weöresi szónak nem azonosítható az ógörögből. (erről MAYER PÉTER tájékoztatott, akinek szíves segítségét itt is köszönöm). A versben a jóslásra vonatkoztatható rész után - miként a kiszámolós gyermekjáték-szövegben az utolsó nyelvi egység megnevezi a játék valamelyik kitüntetett szereplöjét -

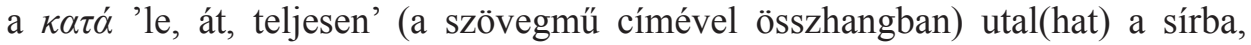
az enyészetbe jutásra: „Már arcod esőben elolvad”; itt az eső 'csapadék' szóra ráértértéssel az esö igenév is lehet fönévként: '(le)esés, zuhanás közben', vagyis a halál vagy temetés bekövetkeztekor (vö. ÉrtSz. esik 4. b).

Az Ócska sírversek cím után következő, a népi sírversek humorát idéző többi hattal együtt a sajátjának szántat mintegy a kiszámolós gyermekjáték nyelvi anyagához is hasonlatossá teszi az ógörög szavak közé tett téni szóval. Országszerte ismeretesek (sok változatban) az ,éni péni jupi téni - effer geffer gumi néni ipsziló ipsziló - te vagy a fogó" vagy az ,an tan téni - szó raka téni” mintájú kiszámolók (vö. TÁTRAI 1988: 596). Ezek a különféle romlott szóanyagból fölépülő ritmusos szövegek a téni szó révén is kapcsolatba hozhatók a varázsszövegek, jósszövegek hasonlóképp sokszor érthetetlen szóanyagával.

„A mántikaténi katá egy ösi görög mágikus dal idézetével kezdődik” - írja SZEPES (1992: 186), egy másik dolgozatában az érthetetlenséget is említi: „ezek itt nem az eredeti ókori hangzást imitáló halandzsaszavak [...], hanem valóban ógörög szavak, a megtévesztés kedvéért egybeírva, $\mathrm{s}$ a görög varázslás, a mantika szavát rejtik" (SZEPES 1995: 145-146); arra nem tér ki, hogy a mantika mellett melyek és milyen jelentésüek az egyéb ógörög szavak, a mágikus dal forrását sem adja meg.

Megjegyzendő: a költő A zivatar szerenádja című versében hasonló hangzású kifejezést használ (háromszor ismételve): „emlékeimet írhassam neked, kedvesem, akit úgy hívok: Mántiki-tiki-múló” (Weöres 2013b: 336, jegyzet: „Megjelent: Válasz 1948. I., 15. o. Valószínüleg korábbi mü”). A SzEPES által említett halandzsaszavakkal való beszéd, illetőleg maga a halandzsa szó Karinthy Frigyes leleménye, két karcolatában mutatja be: Halandzsa, A diadalmas halandzsa (Karinthy 1958; vö. BÜKY 2017). A halandzsa -mondhatni: technológiájával - Vas István In flagranti címmel szonettet írt, amelynek keletkezését és bizonyos vonatkozásait hosszasan taglalta (Vas [1985]). A müvet KÁLMÁN C. (2008) tulajdonképpen halandzsaversnek tartja az ilyen szövegmüvek fordítási kérdésével foglalkozva. ${ }^{1}$

A Weöres Sándor-i líra egyes jegyeinek és a költő bizonyos nyilatkozatainak kapcsán - némileg felszínes - megállapítások is olvashatók éppen e tárgyban, például: „Hubay [Miklós] is Weöres-rajongó volt, elővettük a köteteket (nálam is volt) és elkezdtük a verseket olvasni magyarul, majd pedig fordítani és magya-

\footnotetext{
${ }^{1}$ Köszönöm cikkem lektorának, KEMÉNY GÁBORnak, hogy figyelmeztetett erre.
} 
rázni. Igazolva láttuk költőnk egyik gondolatát: a vers megértéséhez nem feltétlenül szükséges a szavak jelentésének pontos ismerete (a szavaknak önmagukban gyakran nincs is értelmük: Mántikaténi katá)" (Hollósi 2005: 93).

Weöres másutt is besző ógörög elemeket: „Olyan szép a hal-ének, | Néma bárki fülének: | »Habok szála hova szállna? | thalatta! thalatta! | kár aggódni miatta «" (Aqua viva, Weöres 2009. 2: 51). Az ógörög $\theta \alpha \dot{\lambda} \alpha \tau \tau a$ 'tenger' szólássá Xenophón Anabaszisz címü mủvéből vált; örömükben kiáltották a haza felé vonuló, Anatólia hegyeiben elcsigázódott görög katonák, amikor a Thékész hegyröl meglátták a tengert (Xenophón /1968: 160). A szólás a 19. század nyelvészeinek még szaknyelvhasználatában is föllelhető: „Thalatta! itthon vagyunk kiáltám föl” (BÁNÓCZI 1882: 158); a szépirodalomban Kosztolányi Dezső (1981: 60) az Esti Kornélban használja föl a szólást.

A Barbár dal he része („Ole dzsuro nanni he - Könnyemmel mosdattalak”) szintén alaktani elemnek tetszik mindhárom előfordulásában. Ugyanakkor a Képzelt eredeti és képzelt fordítás (Variáns) címmel közölt mü (Weöres 2013b: 348) szintén tartalmazza, de itt a weöresi nyersfordítás alapján 'nem' jelentésủ tagadószóként szerepel, ezt támasztja alá ennek a képzelt fordításnak utolsó szövegmondata is.

\begin{tabular}{|c|c|c|c|}
\hline $\begin{array}{l}\text { TIJ } \\
\text { víz }\end{array}$ & $\begin{array}{l}\text { SZISSZ } \\
\operatorname{mos}\end{array}$ & $\begin{array}{l}\text { KAOHIAO } \\
\text { mohos kövek }\end{array}$ & \\
\hline$V \ddot{U}$ & $O M M O$ & $J E$ & AJO \\
\hline te & öreg & enyém & anya \\
\hline \multicolumn{2}{|c|}{$\begin{array}{l}\text { HJAOKEVÜ } \\
\text { rejtett }\end{array}$} & $\begin{array}{l}\text { AMÉHIH } \\
\text { sokkal }\end{array}$ & 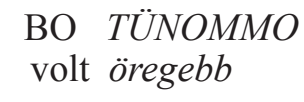 \\
\hline $\begin{array}{l}J O \\
e ́ n\end{array}$ & $\begin{array}{l}H E \\
\text { nem }\end{array}$ & $\begin{array}{l}\text { VEN } \\
\text { hozzád }\end{array}$ & $\begin{array}{l}\text { KONU GORU } \\
\text { hasonló majd }\end{array}$ \\
\hline 2 & $\begin{array}{l}H E \\
\text { nem }\end{array}$ & & \\
\hline
\end{tabular}

Víz mossa a mohos köveket

Mily vén vagy anyám!

Aki eltemette, mégvénebb [ग: még vénebb] volt.

Én nem lehetek hozzád hasonló, nem, soha.

A jo 'én', a vü 'te', előbbihez a je 'enyém', utóbbihoz talán morfológiailag is kapcsolható a ven '(te)hozzád'. Az ajo 'anya', az ommo szót öreg, illetöleg vén megfelelővel használja. A szó melléknév, középfokban a fordítás szerint: tünommo; a végső fordításban: még vénebb. A konu 'hasonló', az elü 'soha'. Három szó marad a fordításban - améhih, bo, goru -, amelyek a „fordításban” nem azonosíthatók magyarral. Ez a weöresi szöveg kialakulásában mutatja a költött nyelv születését. 
Alaktani azonosság van a Barbár dal shukomo, gulmo és dzsárumo szavai között, ugyanis a képzelt fordításban egyes számbeli harmadik személyü felszólító módú igealakok (teremjen, adjon, eltemessen) vannak, amelyek a $-M O$ szóelem révén észlelhetők. A barbár dal szövegének kétféle nyelvét összehasonlítva megmutatkozik a jelentésbeli és szerkezeti rend, amelyet segít észlelni a vers írásképének kéthasábos tördelése. PETŐFI S. JÁNOS (1981: 43) föl is sorol néhány megfelelést - így a jaman = ajaj-t is - bizonyítandó, hogy „valóságos fordítás is lehetne", amely megállapítás a költő címadása után nem mond sokat. Egyik hangfelvételemen (amelynek történetét 1. BÜKY 2013) a barbár nyelvezet minémüségéről ezt mondja Weöres: „A Barbár dal, a képzelt nyelvü szöveg tulajdonképpen cigányos akcentusokkal van tele. Kelet-európai, balkáni, moldvai ízekkel - keverve már kissé európai szóanyaggal. Az oddá [sic!] szó benne például ádder, fáter [ = Vater] germán eredetü, más szavak inkább cigány és román eredetre mutatnak." - A költő nyilatkozatában meglehetősen szabadon bánik a kelet-európai és egyéb nyelvi ízekre utalás révén a vers barbár hátterével. Éppen az odda-val kapcsolatosan érdemes a figyelemre: „A latin pater 'atya' szó indoeurópai $t$-jének pl. a germán nyelvekben zöngés * $\delta$ felel meg, ld. a father (n. Vater)" - írja HUTTERER (1986: 52). A germán nyelvek összetartozását jól szemléltető rokonsági nevek közt gót fadar, újsvéd fa(de)r, németalföldi vader, jiddis foter van (1. HUTTERER 1986: 371), ám odda oddá nem lelhetö föl.

Egy másik hangfelvételen, amely Londonban készült a Szepsi Csombor Kör estjén 1966-ban, a Szabad Európa Rádióban elhangzott felvételen ezt mondja a költő: „A vers meséje, ami nincs elmondva, egy nő haragszik, gyülölködik, átkozódik egy férfira. Lehet, hogy egy élő nő, lehet, hogy csak a nőnek a halott szelleme, mindenesetre egy rendkívül elkeseredett, öö, éles női tiltakozás a férfi ellen" -, és azt, hogy „képzelt cigányos karakteres nyelven” van megírva. (A hangfelvétel saját archívumomban. B. L.) A szavak közt valóságos nyelvböl származó anyag - mint a szanszkrit formula vagy az ógörög - a Barbár dalban többször visszatérő Jaman.

Ezt a szót ismerhette Weöres Lermontov Korunk hőse címủ müvéből: „Urusz jaman, jaman! - üvöltötte [Kazbics, mert ellopták a lovát]” (Lermontov 1966²: 21), eredetiben: „-- Урус яман, яман! - заревел он”, a szó második elöforduláshoz tartozó jegyzet: „2 плохо (тюрк.[ский])" (Лермонтов [1840]). Lermontov regényének több magyar fordítása ismeretes $(1855,1879,1906,1944$, $1956^{1}$ ). A szót Dosztojevszkij egyik regénye, amelynek korai magyar fordítása (Egy halottasház emlékiratai; Dosztojevszkij 1897: 45) szintén tartalmazza, hasonlóan a későbbi fordítások is. A szövegrész, amelyben Nurra, aki cserkesz, ezt mondja Wessely László fordításában (és jegyzetével): „Uh, jaman ${ }^{3}$ Allah megharagszik! - ${ }^{3}$ Rossz" (Dosztojevszkij 1975: 165). Az eredeti szövegrész Dosztojevszkij múveinek kritikai kiadásában: „Мне повстречался Нурра. »Яман, яман! сказал он мне, покачивая головою с благочетивым негодованием, ух, яман! Аллах сердит будет! «"; a jegyzet: , „3 Яман - плохо, дурно (татарск. [ий])" (Достоевский 1972: 109, 306). A versbeli jaman tehát nemcsak a Weöres „képzelt fordítás”-ában, hanem valóban 'jaj, ajaj' jelentésü.

2.3. A költő Táncdal címü, „panyigai panyigai panyigai | ü panyigai ü” kezdetủ versében a panyigai szó eredete ismeretes, az $\ddot{u}$ - például a vers zárlatában: 
„kudora ház panyigai | ü panyigai ház kotta” - esetleg a tánclépés, dobbantás hangját utánzó szó (vö. BÜKY 2012-2013). A kudora eredete lehet Kudora Károly (1851-1916) neve, akinek Könyvtártan (1893) címủ mủvét Weöres könyvtáros korában - abban az időben jelent meg a vers - ismerhette. Hasonlóképp Vas-Witteg Miklós szociáldemokrata képviselő nevét is fölhasználta a Vas Witteg verscímben a költő (Weöres 2009. 3: 208); erre KEMÉNY (1998: 314-5) figyelt föl.

3. A különböző helyeken ismétlődő szavak föltehető jelentése nem egyezik, vagyis nincs egységes képzelt nyelvről szó, csupán az egy-egy szövegmüben ismétlődők jelentése azonos, s voltaképpen ez a helyzet az esetleges grammatikai formák esetében is. A föntebb vizsgálatba vont irodalmi szövegművek jelenségei mutatják, hogy Weöres Sándor nemcsak lírát mint olyat költött, hanem nyelvköltési mutatványokkal is élt.

Kulcsszók: lettrizmus, képzelt nyelv, költői nyelv, Weöres Sándor.

\section{Hivatkozott irodalom}

BÁNÓCZI JÓZSEF 1882. A bölcselet nyelve. Magyar Nyelvőr 11: 158-161.

BATA IMRE 1979. Weöres Sándor közelében. Magvető Könyvkiadó, Budapest.

BEKE JózSEF 2017. Arany-szótár. Arany János költői nyelvének szókészlete. Anyanyelvápolók Szövetsége - Inter, Budapest.

Bibl. 1975 = Biblia. Istennek az Ószövetségben és Újszövetségben adott kijelentése. Református Zsinati Iroda, Budapest.

Bibl. 1976 = Biblia. Ószövetségi és Újszövetségi Szentírás. Szent István Társulat, Budapest. BÜKY LÁsZLÓ 2008. A Füst Milán-i nean. Irodalomtörténeti Közlemények 112: 599-602. BÜKY LÁSZLÓ 2012-2013. Egy költői szövegmü elfogadhatóságának háttere(i) - Weöres Sándor: Táncdal. Nyelvtudomány 19-21.

BÜKY LÁsZLó 2013. Weöres Sándor és a zalai postamester. Pannon Tükör 6: 49-51.

BÜKY LÁsZLÓ 2017. „A pö, ha engemély kimár...” Édes Anyanyelvünk 39/1: 3.

Dosztojevszkij [Fjodor M.] 1897. Egy halottasház emlékiratai - Regény Dosztojevski után oroszból ford. Ford. Timkó Iván. Athenaeum Irodalmi és Nyomdai Rt., Budapest.

Достоевский, Фёдор М. 1972. Записки из Мертвого дома. Полное собрание сочинений в тридцати томах. Том четвертый. Наука, Ленингад. 109-306.

Dosztojevszkij, Fjodor M. 1979. Feljegyzések a Holtak házából. Ford. Wessely László. Európa Könyvkiadó, Budapest.

ÉKsz. ${ }^{2}$ = Magyar értelmező kéziszótár. Főszerk. PUSzTAI FERENC. 2., átdolgozott kiadás. Akadémiai Kiadó, Budapest, 2003.

ERDŐDI JÓZSEF 1954. Egy babona európai útja (Frászkarika). Magyar Nyelv 50: 83-90. EWUng. = Etymologisches Wörterbuch des Ungarischen 1-2. Hrsg. BENKÖ, LORÁND. Akadémiai Kiadó, Budapest, 1993-1995.

ÉrtSz. = A magyar nyelv értelmező szótára $1-7$. Főszerk. BÁRCZI GÉZA - ORSZÁGH

LÁszló. Akadémiai Kiadó, Budapest, 1959-1962.

FÓNAGY IVÁN 1989². A költői nyelv hangtanából. Akadémiai Kiadó, Budapest.

FORGÁCS ERZSÉBET 2005. Nyelvi játékok. Juhász Gyula Felsőoktatási Kiadó, Szeged. 
Hoffmann OtTó 1996. Mini-tini-szótár. A magyar diáknyelv szinonimaszótára. Janus Pannonius Tudományegyetem Továbbképző Intézet, Pécs.

Holy Bible, The. http://www.gasl.org/refbib/Bible_King_James_Version.pdf (2017. 05. 29.) Hollósi ZsOlt 2005. Beszélgetés Pál József irodalomtörténésszel. Tiszatáj 2005. október: $89-105$.

HutTerer MiKLÓs 1986. A germán nyelvek. Gondolat Kiadó, Budapest.

JAKOBSON, ROMAN 1969. Nyelvészet és poétika. In: JAKOBSON, ROMAN, Hang-Jel-Vers. Gondolat, Budapest. 211-257.

KÁLMÁN C. GYÖRGY 2008. Többnyelvüség és fordítás. 2000 [folyóirat] 5: 62-69.

KárBibl. 1590/1990. Szent biblia. Ford. Károli Gáspár. Helikon Kiadó, Budapest.

Karinthy Frigyes 1956. Plem - plem. In: Karinthy Frigyes, Cirkusz - Válogatott írások 1-2. Szépirodalmi Könyvkiadó, Budapest. 1: 313-314.

Karinthy Frigyes 1958. A halandzsa - A diadalmas halandzsa. In: Karinthy Frigyes, $A z$ egész város beszéli 1-4. Szépirodalmi Könyvkiadó, Budapest. 1: 291-294, 295-298.

Karinthy Frigyes 1984. Mindenféle képes Brehm - vagyis alkalmazott állatisme. In: Karinthy Frigyes, Szavak pergőtüzében. Szépirodalmi Könyvkiadó, Budapest. 13-27.

KEMÉNy GÁBOR 1998. Nagy L. János: Szavak és világok Weöres Sándor verseiben. Szemiotikai szövegtan 11: 313-316.

KenYeres ZolTÁn 1983. Tündérsíp - Weöres Sándorról. Szépirodalmi Könyvkiadó, Budapest.

Kosztolányi Dezső 1981. Esti Kornél. Szépirodalmi Könyvkiadó, Budapest.

LADÁNYI PÉTER 1961. Még egyszer a beszédtöltelékről. Magyar Nyelvőr 85: 299-302.

Лермонтов, Михаил Ю. [1840]. Герой нашево времени. http://lib.ru/LITRA/LER[-] MONTOW/geroi.txt (2017. 05. 29.)

Lermontov, Mihail Ju.1966. ${ }^{2}$ Korunk höse. Ford. Áprily Lajos. Európa Könyvkiadó, Budapest.

Mikszáth Kálmán 1960. A Noszty fiú esete Tóth Marival 1-2. Mikszáth Kálmán Összes müvei 20-21. Akadémiai Kiadó, Budapest.

MNSzt. = Magyar nemzeti szövegtár. MTA Nyelvtudományi Intézet, Budapest. http://corpus.nytud.hu/mnsz/

NSzt. = A magyar nyelv nagyszótára $1-$. Főszerk. ITTZÉS NÓRA. MTA Nyelvtudományi Intézet, Budapest. 2006-.

Peterson, Roger Tory - GuY MOUnfort - Philip ARThur DOMINIC Hollom 1972. Európa madarai. Magyar viszonyokhoz alkalmazta dr. Tildy Zoltán. 2. kiadás. Gondolat, Budapest.

PetöFi S. JÁnOs 1981. Szöveg és jelentés. Magyar Mühely [Párizs] 64: 36-59.

SCHMIDT JÓZSEF 1923. A szanszkrit irodalom története. Az Athenaeum Irodalmi és Nyomdai R.-T., Budapest.

SZATHMÁRI ISTVÁN 1958. Kifejező hangváltozások. In: FÁBIÁN PÁL -SzATHMÁRI ISTVÁN - TERESTYÉNI FERENC, A magyar stilisztika vázlata. Tankönyvkiadó, Budapest. 20-23.

SZEPES ERIKA 1992. sírvers. In: Világirodalmi lexikon 13. Főszerk. SZERDAHELYI ISTVÁN. Akadémiai Kiadó, Budapest.

SZEPES ERIKA 1995. Weöres Sándor: Ócska sírvers. In: SZEPES ERIKA, Olvassuk együtt! Nemzeti Tankönyvkiadó, Budapest. 145-152. 
TÁTRAI ZSUZSANNA 1988. A gyermekkor költészete. In: VARGYAS LAJOS szerk., Magyar népköltészet. Magyar néprajz nyolc kötetben. Akadémiai Kiadó, Budapest. 5: 584-610. TEsz. = A magyar nyelv történeti-etimológiai szótára 1-3. Főszerk. BENKÖ LORÁND. Akadémiai Kiadó, Budapest, 1967-1976.

ÚMTsz. = Új magyar tájszótár 1-5. Főszerk. B. LŐRINCZY ÉVA. Akadémiai Kiadó, Budapest, 1979-2010.

Vas István [1985.] Mégis - Válogatott versek. Szépirodalmi Könykiadó, Budapest.

Weöres Sándor 1968. Merülö Saturnus. Magvető Könyvkiadó, Budapest.

Weöres Sándor 1970a. Egybegyüjtött írások 1-2. Magvető Könyvkiadó, Budapest.

Weöres Sándor 1970b. A vers születése. In: Weöres 1970a. 1: 205-248.

Weöres Sándor 1977. Három veréb hat szemmel. Antológia a magyar költészet rejtett értékeiből és furcsaságaiból. Szépirodalmi Könyvkiadó, Budapest.

Weöres Sándor 1998. Egybegyüjtött levelek 12. Pesti Szalon - Marfa Mediterrán Könyvkiadó, [Budapest].

Weöres Sándor 2013a. Egybegyüjtött költemények 1-3. Egybegyüjtött müvek. Helikon, [Budapest].

Weöres Sándor 2013b. Elhagyott versek. Egybegyüjtött müvek. Helikon, [Budapest].

Xenophón /1968. Anabaszisz. A tízezrek hadjáratának története. Ford. Fein Judit. Európa Könyvkiadó, Budapest.

\section{Sándor Weöres' inventive language use from odda to jaman}

The Hungarian poet Sándor Weöres had written poetry consisting of highly musical but meaningless words well before neo avant-garde had invented letterism. In these poems, and in later ones, we find his own inventions along with Sanskrit (omvá), Ancient Greek (mantikaténi), Finno-Ugric (Ukkon), and Circassian (jaman) words, as well as words or phrases resembling Hebrew, Gipsy or other languages. The probable intended meanings of words invented by the poet himself and reoccurring in various poems do not necessarily coincide across poems though they are constant within the same text. In some poems, even traces of a grammatical system can be seen, as can be concluded from the poet's own Hungarian translations of the texts written in imagined languages. This corroborates the claim that Weöres did not have a unitary imagined language.

Keywords: letterism, invented language, poetic language, Sándor Weöres.

BÜKY LÁSZLÓ 